\title{
Data report: minor element concentrations in pore fluids from the CRISP-A transect drilled during Expedition $334^{1}$
}

\author{
Marta E. Torres, ${ }^{2}$ Jesse M. Muratli, ${ }^{2}$ and Evan A. Solomon ${ }^{3}$
}

\section{Chapter contents}

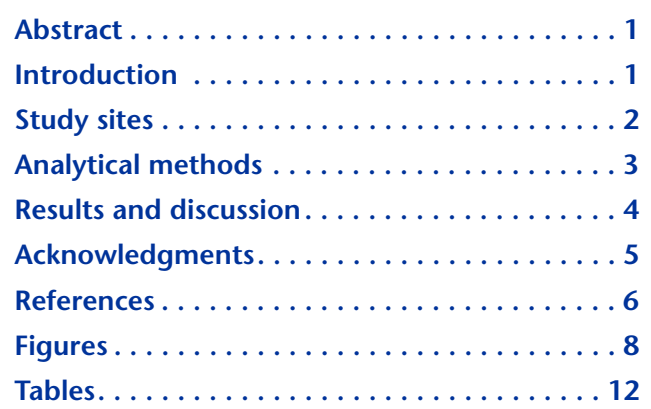

'Torres, M.E., Muratli, J.M., and Solomon, E.A., 2014. Data report: minor element concentrations in pore fluids from the CRISP-A transect drilled during Expedition 334. In Vannucchi, P., Ujiie, K., Stroncik, N., Malinverno, A., and the Expedition 334 Scientists, Proc. IODP, 334: Tokyo (Integrated Ocean Drilling Program Management International, Inc.).

doi:10.2204/iodp.proc.334.201.2014

${ }^{2}$ College of Earth, Ocean, and Atmospheric Science, 104 CEOAS Administration Building, Oregon State University, Corvallis OR 97331, USA. Correspondence author:

mtorres@coas.oregonstate.edu

${ }^{3}$ School of Oceanography, University of Washington, Seattle WA 98195, USA.

\begin{abstract}
We report on the minor element composition of pore fluids recovered during Integrated Ocean Drilling Program (IODP) Costa Rica Seismogenesis Project (CRISP) Expedition 334 from two sites (U1378 and U1379) drilled in the slope sediments of the overriding Caribbean plate and one site (U1381) that sampled sediments in the incoming Cocos plate. $\mathrm{Sr}, \mathrm{Ba}, \mathrm{Li}, \mathrm{B}$, and $\mathrm{Mn}$ were measured using a Leeman Labs Prodigy inductively coupled plasma-optical emission spectrometry, on acidified dilutions of pore water samples at Oregon State University. $\mathrm{H}_{4} \mathrm{SiO}_{4}$ concentrations were determined colorimetrically in unacidified samples using a Thermo Scientific Genesys 10s Vis spectrophotometer at the University of Washington.

In the slope sediment, alteration of reactive ash layers exerts a control on $\mathrm{H}_{4} \mathrm{SiO}_{4}$ concentrations and leads to increases in $\mathrm{Ba}$ and to some degree $\mathrm{Mn}$. Sr is also released from this reaction, but the pore water profiles also reflect carbonate diagenesis, which is also known to occur in these sediments. Li increases with depth and has a discrete maximum at a shear zone that marks the unconformity between the slope apron sediments and the underlying margin wedge. B shows an increase over seawater values in the shallowmost sediments, possibly due to release of this element from organic matter alteration. A decrease below the near-surface maxima suggests incorporation of this element on clay minerals.

At the incoming site, the concentration-depth profile of $\mathrm{H}_{4} \mathrm{SiO}_{4}$ reflects lithology with lower concentrations in Unit I and elevated concentrations in Unit II resulting from biogenic silica dissolution. Sr reflects ash alteration within the sediments, and a reversal close to the sediment basement contact indicates diffusional communication with altered seawater in the oceanic basement. Li and Mn profiles are also indicative of diffusional communication with the basement aquifer.
\end{abstract}

\section{Introduction}

The Costa Rica Seismogenesis Project (CRISP) was designed to understand the processes that control fault zone behavior during earthquake nucleation and rupture propagation at erosional subduction zones. The CRISP study area, located offshore the Osa Peninsula of Costa Rica, is part of the active and long-lived subduction erosion from Guatemala to Costa Rica (Ranero et al., 
2000; Ranero and von Huene, 2000; Vannucchi et al., 2004). This area is characterized by low sediment supply, fast convergence rate, abundant plate interface seismicity, and a change in subducting plate relief along strike (see the "Expedition 334 summary" chapter [Expedition 334 Scientists, 2012a]). Arcward of the trench, the lower slope consists of a $10-12 \mathrm{~km}$ wide frontal prism where a modern sediment apron overlies older sediments that may have been deposited on an older fore-arc basin setting. The first phase of this project focuses on sampling of sediments, fluids, and crustal rocks to fully characterize the eroding material before subduction.

A fundamental component of our understanding of the subduction input focuses on sampling sediments, fluids, and crustal rocks because fluids and associated diagenetic reactions affect hydrological parameters (e.g., permeability and pore pressure) and may regulate the mechanical state of the plate interface at depth. Because of time constraints imposed by a short expedition with high recovery and the importance of fully constraining the fluid regime during Integrated Ocean Drilling Program (IODP) Expedition 334, we concentrated our efforts on collecting samples for postcruise studies, and only a limited number of analyses was carried out onboard. Here we report on the concentration of minor elements of samples collected from coring at two slope sites (Site U1378 on the middle slope and Site U1379 on the upper slope) and at one site on the Cocos plate (Site U1381) (Fig. F1). These data were used to complement geochemical interpretations based on shipboard results from a second IODP expedition (344) to this margin in 2012 (Harris, Sakaguchi, Petronotis, and the Expedition 344 Scientists, 2013) and strontium isotopic analyses of fluids collected during both Expeditions 334 and 344 (Ross et al., submitted).

\section{Study sites}

The main aim of Expedition 334 was to characterize the sediments in the upper (Site U1379) and middle (Site U1378) slope of the Caribbean plate and the incoming sediment and igneous crust of the Cocos plate (Site U1381). Complete descriptions of the drilling results are in each site chapter of this volume.

\section{Site U1378}

Site U1378 is located above the unlocked portion of the plate boundary, as indicated by interplate earthquake relocation and geodetic measurements
(LaFemina et al., 2009). The margin here consists of an upper plate framework wedge underlying about $564 \mathrm{~m}$ of slope sediments. Drilling at this site penetrated a landward dipping reflector interpreted as a normal fault cutting through the whole upper plate, which may be directly linked with the plate boundary fluid system. Site U1378 is dominantly composed of a monotonous sequence of silty clay to clay that alternates with widely interspersed centimeterscale sandy layers, which was divided into two main lithostratigraphic units (Fig. F2). Unit I ( 128 m thick) is composed of mainly soft, dark greenish gray terrigenous silty clay. Unit II ( $\sim 386 \mathrm{~m}$ thick) consists predominantly of massive, well consolidated, olivegreen terrigenous clayey silt(stone) and silty clay(stone). Shipboard sedimentologists identified 82 tephra layers, which seem to be quite heterogeneous in composition. The lowermost core recovered from Hole U1378B (Core 334-U1378B-63X) contains a $0.97 \mathrm{~m}$ thick sequence of extensively fractured silty claystones.

\section{Site U1379}

The shallowest site along the CRISP transect, Site U1379 is thought to overly the locked portion of the subduction zone seismogenic zone in an area where the plate boundary is $4.5 \mathrm{~km}$ below seafloor. The sediments are predominantly a monotonous sequence of silty clay to clay that alternates with widely interspersed decimeter-scale sandy layers. Sediments from Site U1379 are divided into five lithostratigraphic units. Unit I, the relatively thin top unit, consists of medium- to coarse-grained sand with abundant shell fragments. Unit II ( $650 \mathrm{~m}$ thick) is composed of mainly olive-green clayey silt(stone) and silty clay(stone) with minor layers of tephra. The sediments in this unit are massive and well consolidated; the tephra layers are unlithified. Hardened concretions of carbonate mud are present in the interval between Cores 334-U1379C-16H and 40X ( 79-305 meters below seafloor [mbsf]). Unit III ( 229 m thick) consists of fining- and coarsening-upward sequences (decimeter thick) of olive-green silty sands and sandstone. Tephra layers are sparse in this unit, accumulating mainly in one sequence within the upper part of the unit. Unit IV ( $2 \mathrm{~m}$ thick) consists of carbonate-cemented medium- to coarse-grained sand with well-rounded, lithic pebble-sized clasts and thick-walled shell shards. Unit V ( 67 m thick) is composed of matrix-supported breccia with clasts of limestone, basalt, and mudstone in a fine sandy matrix intercalated. Pore waters were sampled only from sediments recovered from lithostratigraphic Units I to III (Fig. F3). Overall, 53 tephra layers (2-45 
$\mathrm{cm}$ thick) were identified intercalated in the background sedimentation of the different units, the majority of them below 324 mbsf.

\section{Site U1381}

Site U1381 targeted the sediment and basement sequences in the incoming Cocos plate. The upper 50 mbsf of sediment at this site is composed of a predominantly monotonous sequence of silty clay to clay (Unit I); which is underlayed by a more pelagic sequence (Unit II), characterized by abundant biogenic components (Fig. F4). The contact between the basement and the overlying sediment was recovered at $\sim 95$ mbsf.

\section{Analytical methods}

Pore fluids were collected from whole-round cores that were cut on the catwalk immediately after recovery, capped, and taken to the laboratory for processing using a titanium squeezer, modified after the stainless-steel squeezer of Manheim and Sayles (1974). Gauge pressures up to $30 \mathrm{MPa}$ were applied using a laboratory hydraulic press to extract pore water. Interstitial water was passed through a prewashed Whatman No. 1 filter fitted above a titanium screen, filtered through a $0.2 \mu \mathrm{m}$ Gelman polysulfone disposable filter, and subsequently extruded into a precleaned $(10 \% \mathrm{HCl}) 60 \mathrm{~mL}$ plastic syringe attached to the bottom of the squeezer assembly. Details of the procedure are given in the "Methods" chapter (Expedition 334 Scientists, 2012b).

For the minor element concentration analyses $(\mathrm{B}, \mathrm{Ba}$, $\mathrm{Fe}, \mathrm{Li}, \mathrm{Mn}$, and $\mathrm{Sr}$ ), the interstitial water sample aliquot was diluted by a factor of 10 (54 of the Hole U1379C samples; $0.25 \mathrm{~mL}$ sample added to $2.25 \mathrm{~mL}$ $1 \%$ nitric acid) or 15 (all other samples; $0.2 \mathrm{~mL}$ sample added to $2.8 \mathrm{~mL} 1 \%$ nitric acid). Only B, Ba, and Li data were collected from the 54 Hole U1379C samples that were diluted 10-fold; and these samples were further diluted 20 -fold $(0.2 \mathrm{~mL}$ diluted sample added to $3.8 \mathrm{~mL} 1 \%$ nitric acid, for a total dilution factor of 200) before acquiring Sr data. Iron and Mn data were not acquired for these samples. Because of the high concentration of matrix salts in the interstitial water samples at the 10- and 15-fold run dilutions, matrix matching of the calibration standards was necessary to achieve accurate results by inductively coupled plasma-optical emission spectrometry. To this end, a matrix solution was prepared from trace-metal-pure salts $\left(\mathrm{NaCl}, \mathrm{CaCl}_{2}\right.$, and $\mathrm{MgSO}_{4}$; Sigma Aldrich, USA). These ultrapure salts contributed a not insignificant amount of Ba to the solution, determined to be $\sim 13 \mathrm{nM}$. This contribution was accounted for when we determined the Ba concentrations in the calibration standards.

The calibration standards used for acquiring $\mathrm{B}, \mathrm{Ba}$, and $\mathrm{Li}$ data from the 10 -fold diluted samples were made in $1 \%$ nitric acid from $1000 \mu \mathrm{g} / \mathrm{mL}$ primary standards (Ultra Scientific, USA) and matrix-matched using our matrix solution. Calibration standard dilutions were done by weight, allowing for a concentration to be calculated in each solution. Standards ranged from 0.178 to $18.2 \mu \mathrm{M} \mathrm{Li}, 11.3$ to $1155 \mu \mathrm{M} \mathrm{B}$, and 10.3 to $917 \mathrm{nM} \mathrm{Ba}$ (accounting for Ba contributed from the matrix solution). Calibration standards used to calculate $\mathrm{Sr}$ in these samples were diluted by weight with $1 \%$ nitric acid from an in-house stock solution containing $1 \mu \mathrm{g} / \mathrm{mL}$ Sr. These standards were not matrix-matched to the samples, as we assumed the 200-fold dilution would dilute the sample matrix sufficiently. The standards ranged from 0.0441 to $2.04 \mu \mathrm{M} \mathrm{Sr}$.

The stock standard solution used while running all other samples was prepared from $1000 \mu \mathrm{g} / \mathrm{mL}$ primary standards (Ultra Scientific and BDH Chemical) in a $1 \%$ nitric acid solution. This solution contained the following concentrations of elements: $\mathrm{B}=108.0$ $\mu \mathrm{M}, \mathrm{Ba}=1.233 \mu \mathrm{M}, \mathrm{Fe}=5.381 \mu \mathrm{M}, \mathrm{Li}=43.99 \mu \mathrm{M}$, $\mathrm{Mn}=5.571 \mu \mathrm{M}$, and $\mathrm{Sr}=27.42 \mu \mathrm{M}$. This standard solution was diluted by weight with $1 \%$ nitric acid, with dilution factors of $3,10,30,100$, and 300 , and each dilution was matrix-matched using our matrix solution.

Calibration standards were run multiple times each run day, and the sample concentrations were calculated using a regression of all calibration data points. The daily limit of detection was determined through error analysis of these regressions. The error due to the regression was calculated for each individual standard run, and a second-order polynomial was fit to these error values. The limits of detection reported here are from the point at which the concentration is equal to three times its corresponding error value along this curve. Because this limit was calculated each day, it is variable between runs. Detection limits, corrected for sample dilution, range from 4.3 to $6.4 \mu \mathrm{M} \mathrm{B}, 70$ to $84 \mathrm{nM} \mathrm{Ba}, 0.25$ to $0.34 \mu \mathrm{M} \mathrm{Fe}, 0.82$ to $2.4 \mu \mathrm{M} \mathrm{Li}, 0.19$ to $0.28 \mu \mathrm{M} \mathrm{Mn}$, and 0.67 to 1.1 $\mu \mathrm{M}$ Sr.

Accuracy and precision of the samples were estimated by repeated analysis of IAPSO standard seawater (Ocean Scientific International Ltd., United Kingdom), with a salinity of 34.993 . Values with $2 \sigma$ errors $(n=26)$ were $\mathrm{B}=452 \pm 14 \mu \mathrm{M}, \mathrm{Ba}=631 \pm 31$ $\mathrm{nM}, \mathrm{Li}=25.8 \pm 0.9 \mu \mathrm{M}$, and $\mathrm{Sr}=88.0 \pm 1.3 \mu \mathrm{M}$. Iron and $\mathrm{Mn}$ were always below the detection limit for each day's run. For these elements the average ana- 
lytical precision was estimated from the repeated runs of the standard curves, and was $<5 \%$ for Fe and $\leq 2 \%$ for $\mathrm{Mn}$.

Dissolved silica concentrations were determined on shore with a Thermo Scientific Genesys 10s Vis spectrophotometer at the University of Washington using the colorimetric method described in Gieskes et al. (1991). Briefly, the method is based on the production of a yellow silicomolybdate complex and the subsequent reduction of this complex to yield a blue color. Standards and samples were prepared for analysis by diluting 20 times then adding the molybdate solution to the vials. Approximately $15 \mathrm{~min}$ was allowed for complexation with the molybdate solution before reduction with a solution consisting of metol sulfite, oxalic acid, and sulfuric acid. After addition of the reducing solution, the samples were allowed to sit for at least $3 \mathrm{~h}$ to let the blue color develop before the absorbance was read on the spectrophotometer at a wavelength of $812 \mathrm{~nm}$.

Calibration, check, and drift standards were made from a $3000 \mu \mathrm{M}$ stock solution prepared by dissolving $0.5642 \mathrm{Na}_{2} \mathrm{SiF}_{6}$ in $1000 \mathrm{~mL}$ of artificial seawater ( $\mathrm{NaCl}$ solution with an ionic strength of 0.7). Calibration was achieved with the following standards: $30,60,120,240,360,480,600,900$, and $1200 \mu \mathrm{M}$ $\mathrm{H}_{4} \mathrm{SiO}_{4}$. Two check standards, which were prepared from the stock solution but were not part of the calibration curve, with concentrations of 300 and 500 $\mu \mathrm{M}$ were analyzed during each batch of analyses to monitor analytical accuracy. A $480 \mu \mathrm{M}$ drift standard was analyzed every 5 samples to monitor analytical precision. The average precision of the dissolved silica analyses based on repeated measurement of the 480,300 , and $500 \mu \mathrm{M}$ standards over a 1 month period was $<1 \%$, and the average accuracy based on repeated analysis of the 300 and $500 \mu \mathrm{M}$ check standards was $<1.5 \%$.

\section{Results and discussion}

A total of 241 pore fluid samples were analyzed and the data are listed in Tables T1, T2, and T3.

Downhole distributions of $\mathrm{Sr}, \mathrm{B}, \mathrm{Li}, \mathrm{Mn}, \mathrm{Ba}$, and $\mathrm{H}_{4} \mathrm{SiO}_{4}$ at Sites U1378 and U1379 are shown in Figures F2 and F3. The most striking signature within the slope sediment apron cored at these sites is a concomitant increase in $\mathrm{Ba}$, $\mathrm{Sr}$, and $\mathrm{H}_{4} \mathrm{SiO}_{4}$, which at Site U1379 occurs from $\sim 300$ to $450 \mathrm{mbsf}$, with maximum values of $7400 \mathrm{nM}, 103 \mu \mathrm{M}$, and $435 \mu \mathrm{M}$, respectively. At Site U1378, there is a distinct maximum in $\mathrm{Ba}$ and $\mathrm{H}_{4} \mathrm{SiO}_{4}$ between 10 and $30 \mathrm{mbsf}$, with $\mathrm{Ba}$ ranging from 1067 to $1667 \mathrm{nM}$ and $\mathrm{H}_{4} \mathrm{SiO}_{4}$ ranging from 560 to $700 \mu \mathrm{M}$; however, Sr decreases within these shal- low sediments. In the sediment interval from 200 to $400 \mathrm{mbsf}$, there are additional broad maxima in $\mathrm{Ba}$ (maximum $=7500 \mathrm{nM}$ ) and $\mathrm{H}_{4} \mathrm{SiO}_{4}$ (maximum $=740$ $\mu \mathrm{M}$ ) and a slight but distinct $\mathrm{Sr}$ maxima (maximum = $56 \mu \mathrm{M}$ ). Whereas this preliminary data set is not enough to fully constrain the reactions leading to these concentration changes, it is likely that the maxima in $\mathrm{Ba}$ and $\mathrm{H}_{4} \mathrm{SiO}_{4}$ are associated with alteration of reactive volcanic ash layers and dissolution of biogenic opal, and the Sr concentration reflects both ash alteration and carbonate diagenesis. At Site U1379 only two tephra layers are recognized in the uppermost $324 \mathrm{~m}$ of sediment, whereas 29 tephra layers were recognized between 309 and 500 mbsf, which correspond to the broad concentration maxima in $\mathrm{Ba}, \mathrm{Sr}$, and $\mathrm{H}_{4} \mathrm{SiO}_{4}$. Intense ash alteration within this interval is confirmed by a marked decrease in the ${ }^{87} \mathrm{Sr} /{ }^{86} \mathrm{Sr}$ ratios measured in pore fluids (Ross et al., submitted). Tephras at Site U1378 are more widely distributed (Fig. F2). In Unit I, shipboard sedimentologists identified 21 tephra layers, widely distributed within the background silty clay sediment. Alteration of these silicates releases $\mathrm{H}_{4} \mathrm{SiO}_{4}$, $\mathrm{Ba}$, and $\mathrm{Sr}$ to the pore fluids. From the 49 tephra horizons described in Unit II, 38 occur between 205 and $333 \mathrm{mbsf}$, which is also consistent with the pore water profiles. A decrease in strontium isotope values occurs at Site U1378, but the isotopic distribution at Site U1378 is less congruent with Sr concentration data, possibly due to more carbonate diagenesis at this site (Ross et al., submitted).

Li and B profiles reported from the Costa Rica margin offshore Nicoya (Chan and Kastner, 2000; Kopf et al., 2000) and convergent margins elsewhere (Moriguti and Nakamura, 1998, Teichert et al., 2005) have shown these elements to be modified in response to moderate to high temperatures. $\mathrm{Li}$ is released from solid phases at high temperatures, whereas B concentration in fluids have been shown to decrease as alteration proceeds. Li concentrations measured in samples from Sites U1378 and U1379 are lower than seawater values $(26 \mu \mathrm{M})$ and are relatively constant in the upper 200 mbsf. Deeper than $200 \mathrm{mbsf}$, there is an increase in concentration with depth, which at Site U1379 leads to a maximum of $74 \mu \mathrm{M}$ at the bottom of the hole, suggesting diffusional interaction with fluid at a greater depth, where higher temperatures prevail. At Site U1378, Li concentrations increase rapidly to a maximum value of $59 \mu \mathrm{M}$ at $490 \mathrm{mbsf}$, followed by a slight decrease to the base of the hole. The zone of elevated Li concentrations at Sites U1378 and U1379 correlates with the broad shear zone observed above the unconformity between the slope apron and underlying wedge material. At Site U1378, this zone extends from $\sim 480$ 
to 550 mbsf and corresponds to a horizon with depleted $\mathrm{Cl}$ and $\mathrm{Ca}$ concentrations, suggesting that the shear zone supports migration of fluids that originated from a source depth where temperatures are $>80^{\circ} \mathrm{C}$ (see the "Expedition 334 summary" chapter [Expedition 334 Scientists, 2012a]; Torres et al., 2013). The decrease in Li concentrations below the shear zone at Site U1378 reflects the presence of a fluid at depth that has interacted with sediment and/ or oceanic basement at a lower temperature. These inferences were confirmed by drilling deeper at this location during Expedition 344 (Harris, Sakaguchi, Petronotis, and the Expedition 344 Scientists, 2013; Torres et al., 2013).

Marine sediments constitute a major reservoir for boron (Ishikawa and Nakamura, 1993), an element that is a highly mobile and is involved in various diagenetic processes. An increase in concentration over the seawater value of $450 \mu \mathrm{M}$ has been observed at various margin settings, and has been attributed to microbial alteration of organic matter, ammonium exchange reactions, and release from clays at higher temperatures (You et al., 1993, 1995). Although small, the shallow slope sediments cored at Site U1379 show slight enrichments in dissolved B (to $472 \mu \mathrm{M})$, and a more developed enrichment is apparent in shallow sediments from Site U1378, with values ranging from 493 to $594 \mu \mathrm{M}$ in the upper 30 mbsf. Below these shallow maxima, B concentrations decrease with depth to values as low as 180 and 100 $\mu \mathrm{M}$ at Sites U1378 and U1379, respectively. Detrital clay minerals initially adsorb B onto the mineral surface, and with increasing burial during late diagenesis, this element is incorporated in tetrahedral sites of the clay structure, replacing $\mathrm{Si}$ (Williams et al., 2001). However, B is released during smectite to illite conversion, as documented experimentally and in field observations (Williams et al., 2001; Teichert et al., 2005; You et al., 1995). The lack of an increase in $\mathrm{B}$ concentrations with depth at these CRISP slope sites suggests that the B released at depth is overprinted by sorption and incorporation onto clays; a very slight concentration increase at the shear zones may be indicative of a component of clay dehydration reactions, evidenced in the low $\mathrm{Cl}$ values measured in pore fluids from the shear zone (see the "Expedition 334 summary" chapter [Expedition 334 Scientists, 2012a]). However, full evaluation of the processes driving $\mathrm{B}$ reactions in the CRISP region awaits results from boron isotopic analyses (Solomon laboratory, in progress).

Mn concentrations at Sites U1378 and U1379 are highly variable, and the discrete maxima in the re- ducing fluids at these sites possibly indicate alteration of Mn-bearing tephras.

Downhole distributions of $\mathrm{Sr}, \mathrm{B}, \mathrm{Li}, \mathrm{Mn}, \mathrm{Ba}$, and $\mathrm{H}_{4} \mathrm{SiO}_{4}$ at Site U1381 are shown in Figure F4. Sr concentrations are close to a modern seawater value of $86 \mu \mathrm{M}$ from the seafloor to $\sim 45 \mathrm{mbsf}$ and increase slightly downhole from $\sim 45$ to $\sim 95$ mbsf to a maximum concentration of $104 \mu \mathrm{M}$. In the deepest $\sim 10 \mathrm{~m}$ of the hole, Sr concentrations decrease slightly toward the sediment/basalt interface. The minor decrease in $\mathrm{Sr}$ concentrations observed at the base of the hole must be related to reactions in the oceanic basement, as confirmed by strontium isotope data (Ross et al., submitted).

In the shallowest sample analyzed at $\sim 1.5 \mathrm{mbsf}$, $\mathrm{H}_{4} \mathrm{SiO}_{4}$ concentration $(538 \mu \mathrm{M})$ is higher than bottom water concentration, which in this region is $\sim 180 \mu \mathrm{M}$. Silica concentrations increase with depth to $\sim 1080 \mu \mathrm{M}$, possibly in response to the dissolution of siliceous phyto- and zooplankton diatoms, radiolarians, and sponge spicules observed in larger abundances in lithostratigraphic Unit II (see the "Expedition 334 summary" chapter [Expedition 334 Scientists, 2012a]).

$\mathrm{Ba}$ concentrations throughout the sediment section are very low, between $\sim 250$ and $730 \mathrm{nM}$, and slightly above the bottom seawater concentration of $\sim 240$ $470 \mathrm{nM}$. These concentrations are typical of pore fluid $\mathrm{Ba}$ values in the pelagic environment, where sulfate concentrations are too high for barite dissolution. No obvious trends are observed in the Ba concentration-depth profile, as expected for this environment. From $\sim 25 \mathrm{mbsf}$ to the bottom of the hole, Mn concentrations increase with depth, similar to the $\mathrm{Li}$ profile. This $\mathrm{Mn}$ increase has a diffusional shape, suggesting communication with deeper fluid in the oceanic basement that has a higher Mn concentration. As observed in the shallow sediments cored in the slope apron, B shows a slight increase over seawater values to $554 \mu \mathrm{M}$, with a general decrease toward seawater values at the bottom of the hole.

\section{Acknowledgments}

This research used samples and data provided by the Integrated Ocean Drilling Program (IODP), which is sponsored by the US National Science Foundation and participating countries and universities under management of IODP Management International, Inc. The outstanding efforts of the Siem Offshore officers and crew as well as the drilling personnel and 
the scientific parties of IODP Expedition 344 are greatly acknowledged here. Without their hard work and dedication, none of these samples could have been recovered for analysis. This research was funded by USSP postcruise research Award T334B11 to M. Torres and Award T334A85 to E. Solomon.

\section{References}

Chan, L.-H., and Kastner, M., 2000. Lithium isotopic compositions of pore fluids and sediments in the Costa Rica subduction zone: implications for fluid processes and sediment contribution to the arc volcanoes. Earth Planet. Sci. Lett., 183(1-2):275-290. doi:10.1016/S0012821X $(00) 00275-2$

Expedition 334 Scientists, 2012a. Expedition 334 summary. In Vannucchi, P., Ujiie, K., Stroncik, N., Malinverno, A., and the Expedition 334 Scientists, Proc. IODP, 334: Tokyo (Integrated Ocean Drilling Program Management International, Inc.). doi:10.2204/

iodp.proc.334.101.2012

Expedition 334 Scientists, 2012b. Methods. In Vannucchi, P., Ujiie, K., Stroncik, N., Malinverno, A., and the Expedition 334 Scientists, Proc. IODP, 334: Tokyo (Integrated Ocean Drilling Program Management International, Inc.). doi:10.2204/iodp.proc.334.102.2012

Expedition 334 Scientists, 2012c. Site U1378. In Vannucchi, P., Ujiie, K., Stroncik, N., Malinverno, A., and the Expedition 334 Scientists, Proc. IODP, 334: Tokyo (Integrated Ocean Drilling Program Management International, Inc.). doi:10.2204/iodp.proc.334.103.2012

Expedition 334 Scientists, 2012d. Site U1379. In Vannucchi, P., Ujiie, K., Stroncik, N., Malinverno, A., and the Expedition 334 Scientists, Proc. IODP, 334: Tokyo (Integrated Ocean Drilling Program Management International, Inc.). doi:10.2204/iodp.proc.334.104.2012

Expedition 334 Scientists, 2012e. Site U1381. In Vannucchi, P., Ujiie, K., Stroncik, N., Malinverno, A., and the Expedition 334 Scientists, Proc. IODP, 334: Tokyo (Integrated Ocean Drilling Program Management International, Inc.). doi:10.2204/iodp.proc.334.106.2012

Gieskes, J.M., Gamo, T., and Brumsack, H., 1991. Chemical methods for interstitial water analysis aboard JOIDES Resolution. ODP Tech. Note, 15. doi:10.2973/ odp.tn.15.1991

Harris, R.N., Sakaguchi, A., Petronotis, K., and the Expedition 344 Scientists, 2013. Proc. IODP, 344: College Station, TX (Integrated Ocean Drilling Program). doi:10.2204/iodp.proc.344.2013

Ishikawa, T., and Nakamura, E., 1993. Boron isotope systematics of marine sediments. Earth Planet. Sci. Lett., 117(3-4):567-580. doi:10.1016/0012-821X(93)90103-G

Kopf, A., Deyhle, A., and Zuleger, E., 2000. Evidence for deep fluid circulation and gas hydrate dissociation using boron and boron isotopes of pore fluids in forearc sediments from Costa Rica (ODP Leg 170). Mar. Geol., 167(1-2):1-28. doi:10.1016/S0025-3227(00)00026-8
LaFemina, P., Dixon, T.H., Govers, R., Norabuena, E., Turner, H., Saballos, A., Mattioli, G., Protti, M., and Strauch, W., 2009. Fore-arc motion and Cocos Ridge collision in Central America. Geochem., Geophys., Geosyst., 10(5):Q05S14. doi:10.1029/2008GC002181

Manheim, F.T., and Sayles, F.L., 1974. Composition and origin of interstitial waters of marine sediments, based on deep sea drill cores. In Goldberg, E.D. (Ed.), The Sea (Vol. 5): Marine Chemistry: The Sedimentary Cycle: New York (Wiley), 527-568.

Moriguti, T., and Nakamura, E., 1998. Across-arc variation of Li isotopes in lavas and implications for crust/mantle recycling at subduction zones. Earth Planet. Sci. Lett., 163(1-4):167-174. doi:10.1016/S0012821X(98)00184-8

Ranero, C.R., and von Huene, R., 2000. Subduction erosion along the Middle America convergent margin. Nature, 404(6779):748-752. doi:10.1038/35008046

Ranero, C.R., von Huene, R., Flueh, E., Duarte, M., Baca, D., and McIntosh, K., 2000. A cross section of the convergent Pacific margin of Nicaragua. Tectonics, 19(2):335-357. doi:10.1029/1999TC900045

Ross, N., Torres, M.E., Haley, B.A., Solomon, E., and Kastner, M., submitted. Data report: strontium isotope analyses of pore fluids from the CRISP-A transect drilled during Expeditions 334 and 344. Proc. IODP, 344.

Teichert, B.M.A., Torres, M.E., Bohrmann, G., and Eisenhauer, A., 2005. Fluid sources, fluid pathways and diagenetic reactions across an accretionary prism revealed by Sr and B geochemistry. Earth Planet. Sci. Lett., 239(12):106-121. doi:10.1016/j.epsl.2005.08.002

Torres, M.E., Solomon, E.A., Kastner, M., Harris, R.N., Formolo, M., Choi, J., Berg, R.D., and Nuzzo, M., 2013. Geochemical evidence for fluid flow in the upper and subducting plates of the Costa Rica margin: results from CRISP drilling during Exp. 334 and 344 [presented at the 2013 American Geophysical Union Fall Meeting, San Francisco, CA, 9-13 December 2013]. (Abstract T34C-02) http://abstractsearch.agu.org/meetings/ 2013/FM/sections/T/sessions/T34C/abstracts/T34C02.html

Vannucchi, P., Galeotti, S., Clift, P.D., Ranero, C.R., and von Huene, R., 2004. Long-term subduction-erosion along the Guatemalan margin of the Middle America Trench. Geology, 32(7):617-620. doi:10.1130/G20422.1

Vannucchi, P., Ujiie, K., Stroncik, N., Malinverno, A., and the Expedition 334 Scientists, 2012. Proc. IODP, 334: Tokyo (Integrated Ocean Drilling Program Management International, Inc.). doi:10.2204/iodp.proc.334.2012

Williams, L.B., Hervig, R.L., Holloway, J.R, and Hutcheon, I., 2001. Boron isotope geochemistry during diagenesis. Part I. Experimental determination of fractionation during illitization of smectite. Geochim. Cosmochim. Acta, 65(11):1769-1782. doi:10.1016/ S0016-7037(01)00557-9

You, C.-F., Spivack, A.J., Gieskes, J.M., Rosenbauer, R., and Bischoff, J.L., 1995. Experimental study of boron geochemistry: implications for fluid processes in subduc- 
tion zones. Geochim. Cosmochim. Acta, 59(12):24352442. doi:10.1016/0016-7037(95)00137-9

You, C.-F., Spivack, A.J., Smith, J.H., and Gieskes, J.M., 1993. Mobilization of boron in convergent margins: implications for the boron geochemical cycle. Geology, 21(3):207-210. doi:10.1130/

0091-7613(1993)021<0207:MOBICM>2.3.CO;2
Initial receipt: 14 April 2014

Acceptance: 23 July 2014

Publication: 10 October 2014

MS 334-201 
Figure F1. A. Location map of the sites drilled during IODP Costa Rica Seismogenesis Project (CRISP). B. Location of Sites U1378, U1379, and U1381 on bathymetry. C. Location of sites on depth-migrated seismic Line BGR99-7. From the "Expedition 334 summary" chapter [Expedition 334 Scientists, 2012a].

A
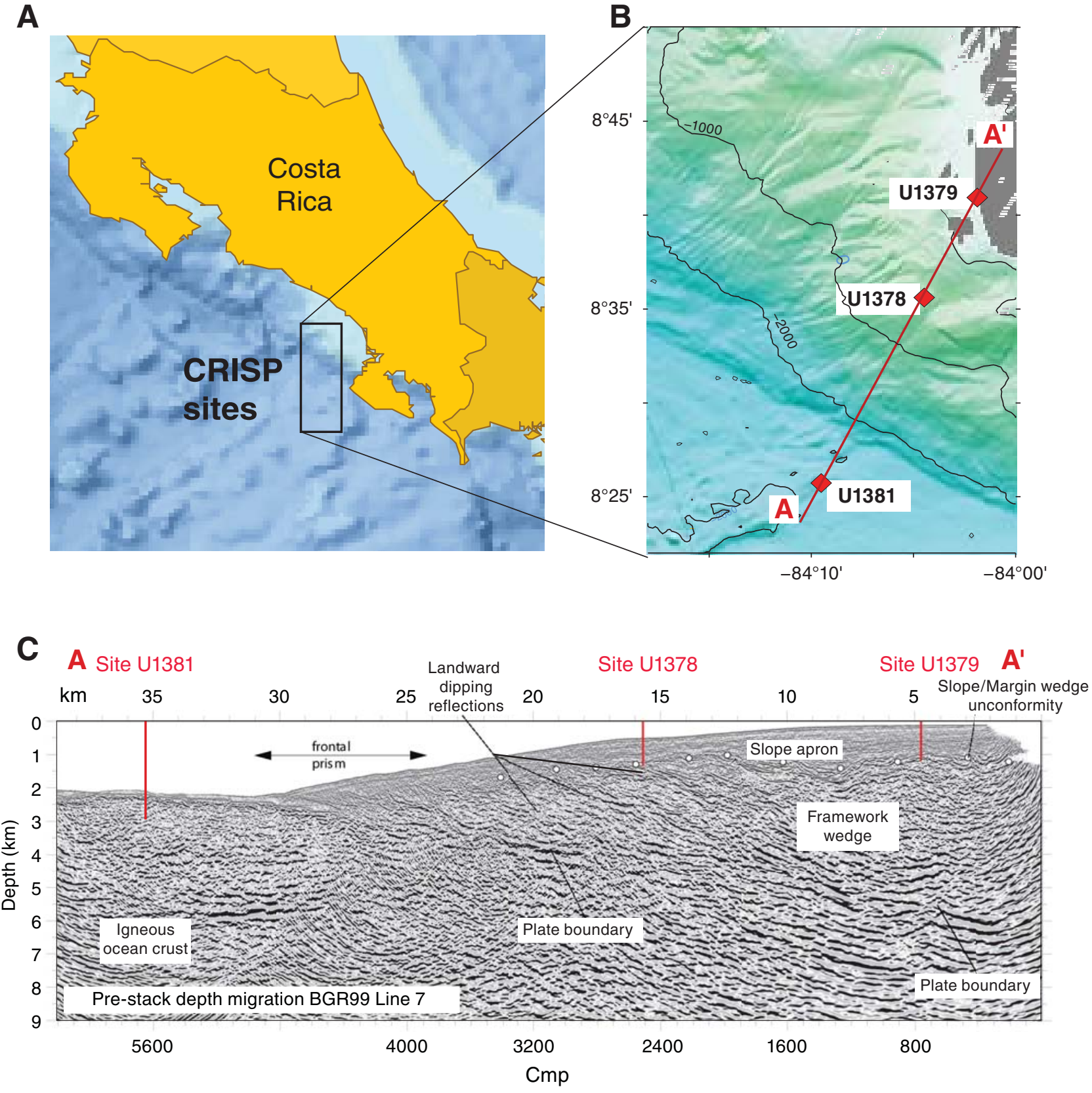
Figure F2. Downhole profiles of strontium, barium, silica, lithium, boron, and manganese, Site U1378. Lithostratigraphic column is redrawn from the "Site U1378" chapter (Expedition 334 Scientists, 2012c). Arrows = bottom seawater values, dashed line $=$ lithostratigraphic unit boundary.
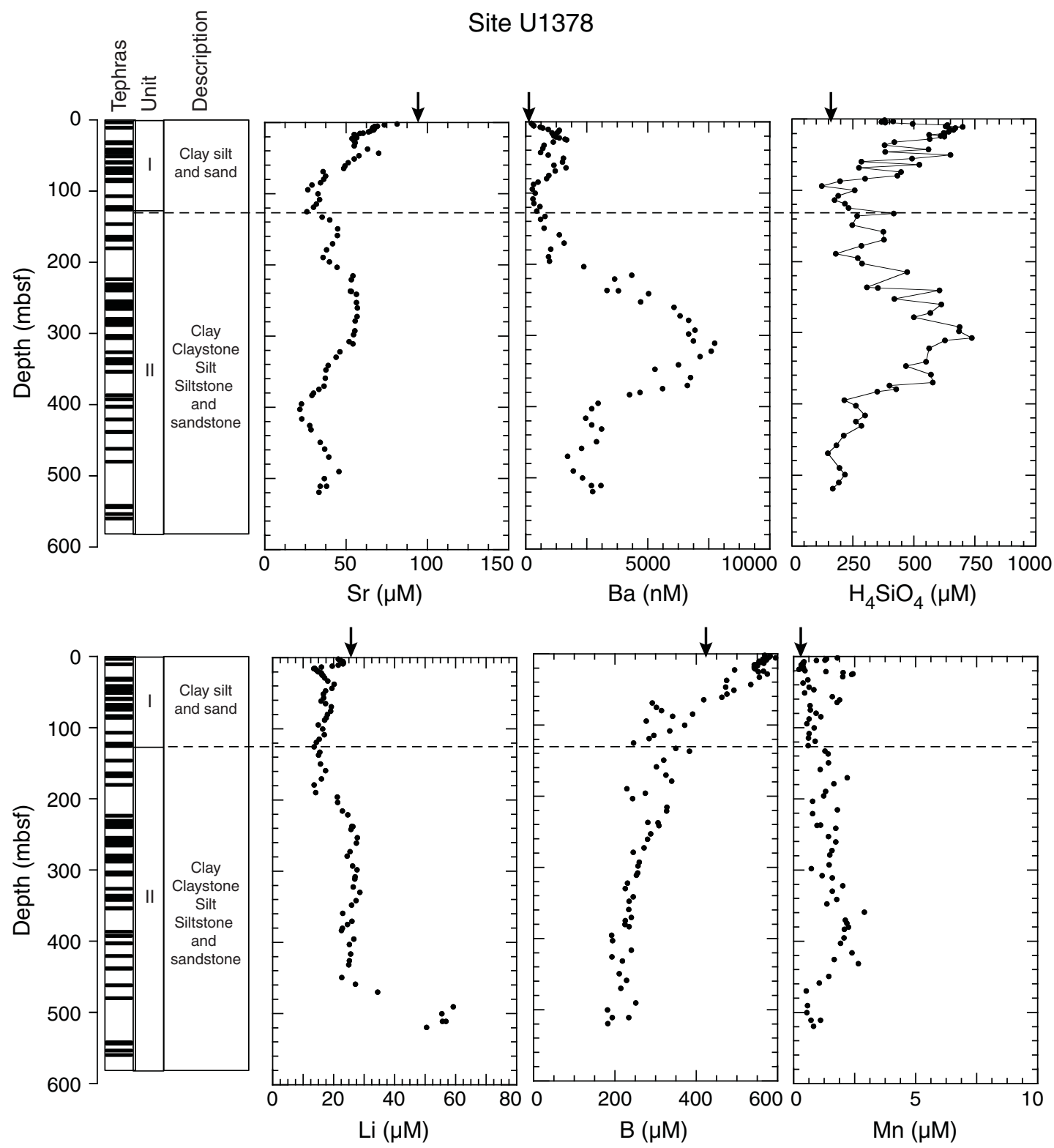
Figure F3. Downhole profiles of strontium, barium, silica, lithium, boron, and manganese, Site U1379. Lithostratigraphic column is redrawn from the "Site U1379" chapter (Expedition 334 Scientists, 2012d). Arrows = bottom seawater values., dashed lines = lithostratigraphic unit boundaries.
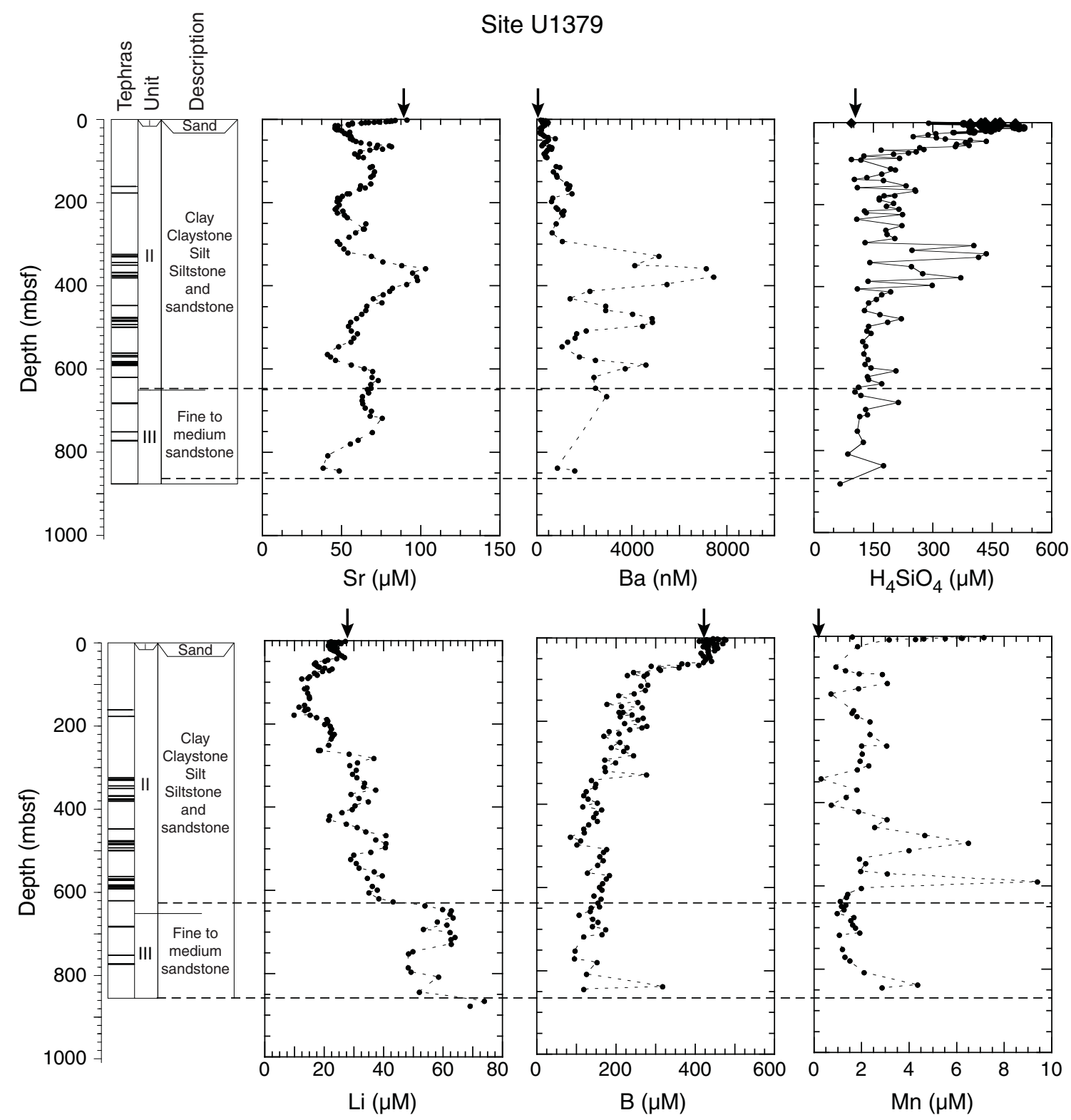
Figure F4. Downhole profiles of strontium, barium, silica, lithium, boron, and manganese, Site U1381. Lithostratigraphic column is redrawn from the "Site U1381" chapter (Expedition 334 Scientists, 2012e). Arrows = bottom seawater values, dashed line = lithostratigraphic unit boundary.

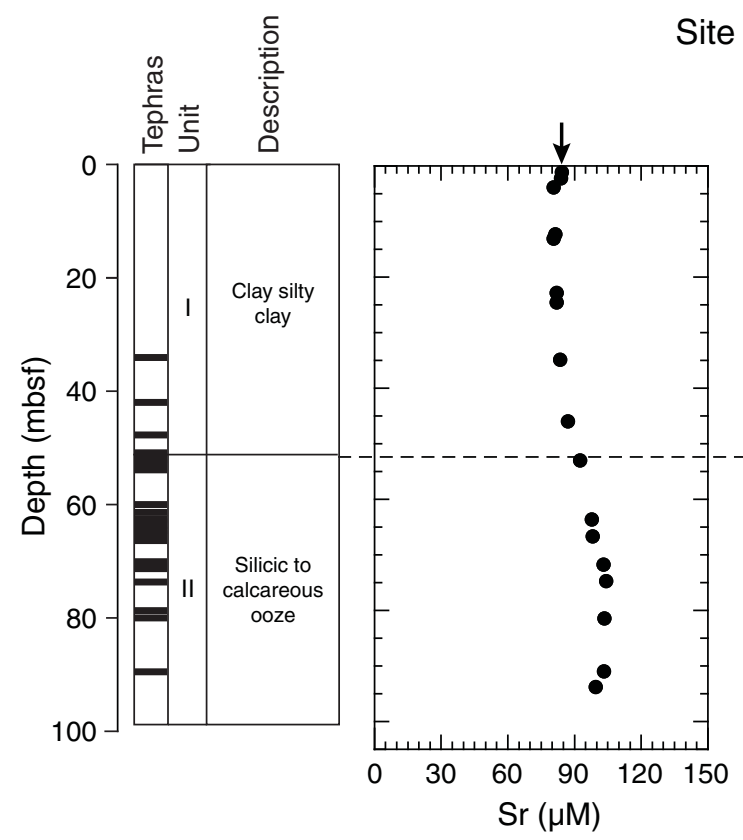

Site U1381
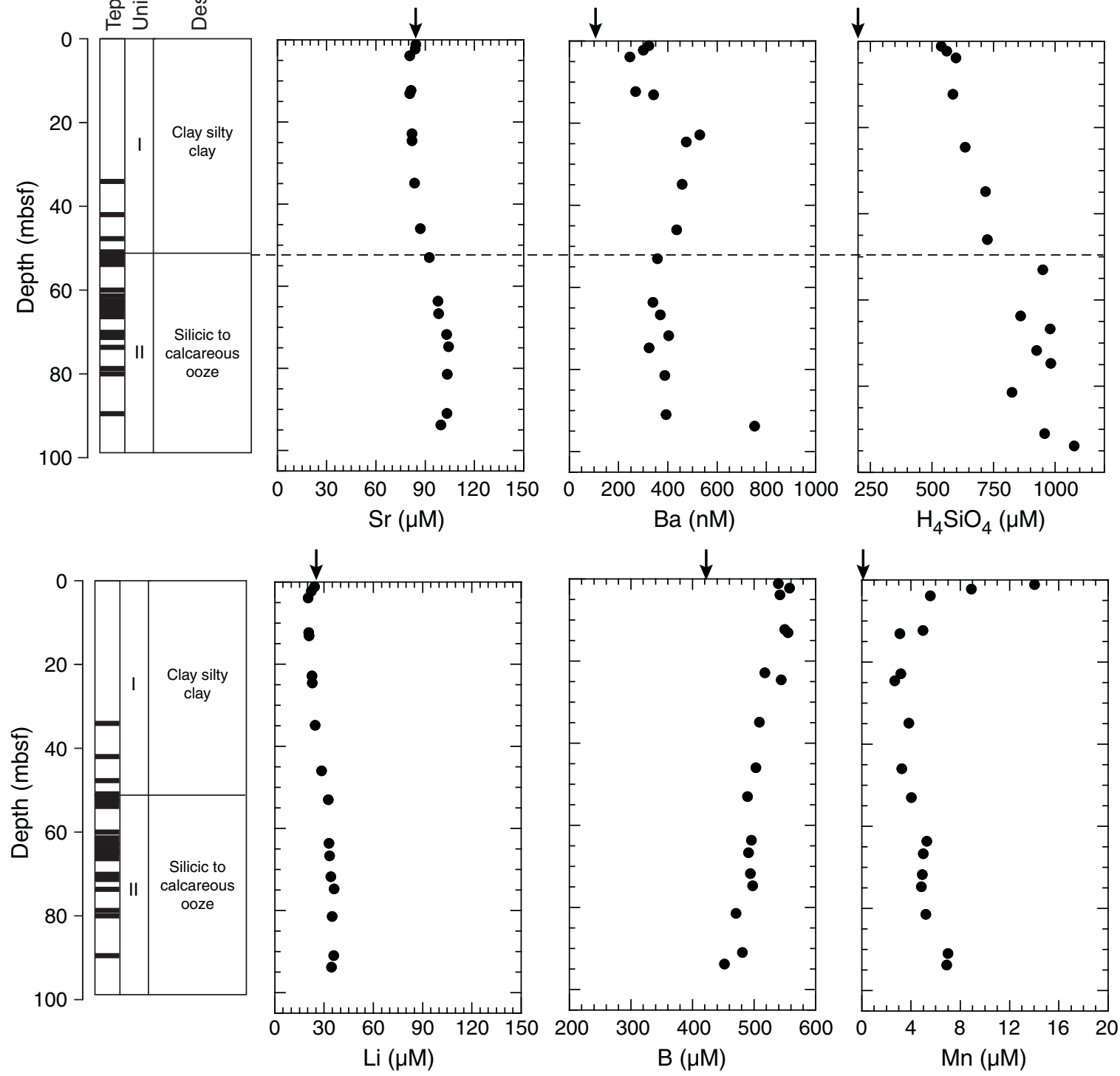
Table T1. Minor element concentrations in pore fluids, Site U1378. (Continued on next page.)

\begin{tabular}{|c|c|c|c|c|c|c|c|c|}
\hline \multirow{2}{*}{$\begin{array}{l}\text { Core, section, } \\
\text { interval }(\mathrm{cm})\end{array}$} & \multicolumn{2}{|c|}{ Depth (mbsf) } & \multirow{2}{*}{$\begin{array}{c}\mathrm{Li} \\
(\mu \mathrm{M})\end{array}$} & \multirow{2}{*}{$\begin{array}{c}\mathrm{B} \\
(\mu \mathrm{M})\end{array}$} & \multirow{2}{*}{$\begin{array}{c}\mathrm{Mn} \\
(\mu \mathrm{M})\end{array}$} & \multirow{2}{*}{$\begin{array}{c}\mathrm{Sr} \\
(\mu \mathrm{M})\end{array}$} & \multirow{2}{*}{$\begin{array}{c}\mathrm{Ba} \\
(\mathrm{nM})\end{array}$} & \multirow{2}{*}{$\begin{array}{c}\mathrm{H}_{4} \mathrm{SiO}_{4} \\
(\mu \mathrm{M})\end{array}$} \\
\hline & Top & Bottom & & & & & & \\
\hline \multicolumn{9}{|l|}{ 334-U1378B- } \\
\hline $1 \mathrm{H}-1,138-150$ & 1.4 & 1.5 & 21.3 & 567 & 1.78 & 81.1 & 252 & 381 \\
\hline $1 \mathrm{H}-2,138-150$ & 2.9 & 3.0 & 21.9 & 581 & 1.33 & 73.2 & 269 & 414 \\
\hline $1 \mathrm{H}-3,138-150$ & 4.4 & 4.5 & 22.7 & 577 & 1.27 & 69.0 & 329 & 370 \\
\hline $1 \mathrm{H}-4,46-58$ & 5.0 & 5.1 & 22.9 & 594 & 0.92 & 67.3 & 325 & 384 \\
\hline $2 \mathrm{H}-1,138-150$ & 6.7 & 6.8 & 23.1 & 562 & 0.41 & 66.0 & 604 & 496 \\
\hline $2 \mathrm{H}-2,138-150$ & 8.2 & 8.3 & 22.9 & 571 & 0.37 & 67.2 & 703 & 637 \\
\hline $2 \mathrm{H}-3,138-150$ & 9.7 & 9.8 & 21.4 & 553 & 0.37 & 66.5 & 912 & 631 \\
\hline $2 \mathrm{H}-4,138-150$ & 11.2 & 11.3 & 19.4 & 558 & 0.29 & 64.9 & 1357 & 700 \\
\hline $2 \mathrm{H}-5,138-150$ & 12.7 & 12.8 & 15.8 & 565 & 0.31 & 63.5 & 1349 & 670 \\
\hline $2 \mathrm{H}-6,138-150$ & 14.2 & 14.3 & 13.6 & 547 & 0.31 & 60.2 & 1320 & 649 \\
\hline $2 \mathrm{H}-7,54-66$ & 14.8 & 15.0 & 13.4 & 542 & 0.38 & 58.2 & 1067 & 663 \\
\hline $3 \mathrm{H}-1,138-150$ & 16.2 & 16.3 & 14.0 & 549 & 0.32 & 54.8 & 1132 & 646 \\
\hline $3 \mathrm{H}-2,138-150$ & 17.7 & 17.8 & 14.4 & 541 & 0.19 & 55.7 & 1179 & 643 \\
\hline $3 \mathrm{H}-3,138-150$ & 19.2 & 19.3 & 14.8 & 541 & 0.45 & 55.0 & 1157 & 624 \\
\hline $3 \mathrm{H}-4,138-150$ & 20.7 & 20.8 & 15.7 & 544 & 1.31 & 56.2 & 1243 & 626 \\
\hline $3 \mathrm{H}-5,138-150$ & 22.2 & 22.3 & 15.9 & 493 & 2.01 & 53.3 & 1363 & 562 \\
\hline $3 \mathrm{H}-6,133-145$ & 23.6 & 23.8 & 16.1 & 564 & 2.41 & 54.8 & 1609 & 612 \\
\hline $3 \mathrm{H}-7,58-70$ & 24.4 & 24.5 & 16.4 & 552 & 2.36 & 54.6 & 1667 & 627 \\
\hline $4 \mathrm{H}-3,138-150$ & 27.8 & 27.9 & 16.9 & 574 & 1.99 & 55.3 & 1143 & 566 \\
\hline $4 \mathrm{H}-6,138-150$ & 32.3 & 32.4 & 17.9 & 554 & 0.57 & 54.6 & 753 & 421 \\
\hline $5 \mathrm{H}-2,138-150$ & 36.7 & 36.8 & 20.0 & 473 & 0.37 & 63.0 & 727 & 380 \\
\hline $5 \mathrm{H}-6,138-150$ & 42.7 & 42.8 & 19.3 & 533 & 0.62 & 69.8 & 611 & 561 \\
\hline $6 \mathrm{H}-2,138-150$ & 46.2 & 46.3 & 17.2 & 471 & 0.81 & 57.7 & 943 & 382 \\
\hline $6 \mathrm{H}-5,138-150$ & 50.7 & 50.8 & 16.5 & 492 & 0.43 & 54.8 & 1546 & 650 \\
\hline 7H-2, 138-150 & 55.7 & 55.8 & 16.5 & 474 & 1.56 & 51.1 & 1518 & 494 \\
\hline 7H-5, 138-150 & 60.2 & 60.3 & 15.8 & 461 & 1.86 & 49.0 & 1145 & 285 \\
\hline $8 \mathrm{H}-2,138-150$ & 63.8 & 63.9 & 17.2 & 417 & 1.75 & 48.2 & 1630 & 524 \\
\hline $8 \mathrm{H}-5,138-150$ & 68.3 & 68.4 & 19.0 & 291 & 0.65 & 35.5 & 1202 & 276 \\
\hline $9 \mathrm{H}-2,138-150$ & 74.7 & 74.8 & 18.8 & 301 & 0.67 & 37.1 & 977 & 448 \\
\hline $9 \mathrm{H}-5,130-142$ & 79.1 & 79.2 & 17.9 & 314 & 0.90 & 36.0 & 858 & 433 \\
\hline $10 \mathrm{H}-2,130-142$ & 84.1 & 84.2 & 17.5 & 390 & 1.09 & 34.1 & 511 & 301 \\
\hline $10 \mathrm{H}-4,138-150$ & 87.1 & 87.2 & 16.9 & 341 & 0.61 & 28.7 & 310 & 198 \\
\hline $11 \mathrm{H}-3,138-150$ & 94.0 & 94.1 & 14.8 & 276 & 0.52 & 26.1 & 286 & 124 \\
\hline $12 \mathrm{H}-3,138-150$ & 99.8 & 100.0 & 16.2 & 371 & 0.83 & 32.4 & 395 & 258 \\
\hline $13 \mathrm{H}-4,138-150$ & 107.9 & 108.0 & 16.8 & 334 & 0.62 & 33.4 & 312 & 190 \\
\hline $14 \mathrm{H}-3,138-150$ & 114.1 & 114.2 & 15.1 & 295 & 0.59 & 31.5 & 330 & 176 \\
\hline $15 \mathrm{H}-2,118-130$ & 118.5 & 118.6 & 14.2 & 283 & 0.87 & 29.7 & 597 & 218 \\
\hline $16 \mathrm{H}-3,133-145$ & 124.8 & 124.9 & 13.4 & 245 & 0.58 & 25.7 & 452 & 233 \\
\hline $17 X-3,133-145$ & 132.1 & 132.3 & 15.3 & 348 & 1.27 & 35.0 & 783 & 418 \\
\hline $18 \mathrm{X}-3,113-130$ & 136.3 & 136.5 & 14.9 & 382 & 1.40 & 39.8 & 629 & 267 \\
\hline $19 X-5,71-96$ & 148.6 & 148.8 & 15.5 & 319 & 1.41 & 44.6 & 759 & 249 \\
\hline $20 X-5,130-153$ & 158.2 & 158.5 & 17.2 & 301 & 1.08 & 44.4 & 1356 & 375 \\
\hline $21 X-7,68-93$ & 169.6 & 169.9 & 15.8 & 325 & 2.18 & 41.5 & 1553 & 378 \\
\hline $22 X-5,88-105$ & 178.2 & 178.4 & 13.4 & 338 & 1.63 & 37.7 & 1007 & 285 \\
\hline $23 X-6,109-126$ & 188.8 & 189.0 & 14.0 & 228 & 1.30 & 35.6 & 922 & 182 \\
\hline $24 X-4,122-150$ & 194.9 & 195.2 & 21.0 & 273 & 1.21 & 39.5 & 966 & 271 \\
\hline $25 X-3,74-90$ & 202.7 & 202.9 & 21.2 & 242 & 0.75 & 44.2 & 2324 & 289 \\
\hline $26 X-4,98-115$ & 214.7 & 214.9 & 22.7 & 327 & 1.77 & 53.9 & 4274 & 474 \\
\hline $27 X-2,100-127$ & 220.0 & 220.3 & 24.5 & 326 & 0.76 & 52.9 & 3549 & \\
\hline $28 X-7,33-65$ & 236.4 & 236.8 & 25.8 & 280 & 1.08 & 52.4 & 3233 & 308 \\
\hline $29 X-3,45-83$ & 236.8 & 237.1 & 26.2 & 305 & 0.94 & 52.9 & 3725 & 353 \\
\hline $30 X-2,110-145$ & 240.9 & 241.3 & 25.6 & 307 & 1.71 & 56.2 & 4958 & 607 \\
\hline $31 X-4,118-150$ & 252.5 & 252.8 & 27.6 & 286 & 1.41 & 56.1 & 4593 & 420 \\
\hline $32 X-3,73-105$ & 259.8 & 260.2 & 27.3 & 279 & 1.71 & 56.7 & 5866 & 614 \\
\hline $33 X-5,58-94$ & 271.9 & 272.3 & 25.2 & 270 & 1.55 & 56.4 & 6189 & 568 \\
\hline $34 X-2,86-122$ & 278.0 & 278.3 & 24.3 & 244 & 1.46 & 55.4 & 6506 & 502 \\
\hline $35 X-5,98-130$ & 292.1 & 292.4 & 26.0 & 259 & 1.43 & 55.1 & 6767 & 687 \\
\hline $36 X-2,93-125$ & 297.6 & 298.0 & 27.5 & 256 & 0.70 & 54.4 & 6482 & 685 \\
\hline $37 X-2,91-123$ & 307.2 & 307.5 & 26.9 & 255 & 1.15 & 51.5 & 6692 & 739 \\
\hline $38 X-1,118-150$ & 310.5 & 310.8 & 26.8 & 252 & 1.56 & 53.9 & 7494 & 629 \\
\hline $39 X-5,118-150$ & 321.7 & 322.0 & 26.3 & 230 & 1.99 & 46.0 & 7361 & 564 \\
\hline $40 X-4,80-92$ & 329.1 & 329.2 & 28.5 & 224 & 1.56 & 43.6 & 6901 & \\
\hline $41 X-5,104-136$ & 340.7 & 341.1 & 27.2 & 244 & 1.74 & 38.7 & 6015 & 551 \\
\hline $42 X-3,64-96$ & 347.0 & 347.4 & 25.8 & 234 & 1.34 & 37.4 & 5145 & 467 \\
\hline $43 X-5,55-87$ & 358.7 & 359.0 & 22.9 & 233 & 2.87 & 36.9 & 6469 & 571 \\
\hline $45 X-3,55-88$ & 369.7 & 370.0 & 25.9 & 240 & 2.10 & 36.1 & 6333 & 578 \\
\hline $46 \mathrm{X}-2,115-150$ & 374.3 & 374.6 & 24.4 & 224 & 2.16 & 33.1 & 5393 & 401 \\
\hline
\end{tabular}


Table T1 (continued).

\begin{tabular}{|c|c|c|c|c|c|c|c|c|}
\hline \multirow{2}{*}{$\begin{array}{l}\text { Core, section, } \\
\text { interval }(\mathrm{cm})\end{array}$} & \multicolumn{2}{|c|}{ Depth (mbsf) } & \multirow{2}{*}{$\begin{array}{c}\mathrm{Li} \\
(\mu \mathrm{M})\end{array}$} & \multirow{2}{*}{$\begin{array}{c}\text { B } \\
(\mu \mathrm{M})\end{array}$} & \multirow{2}{*}{$\begin{array}{c}\mathrm{Mn} \\
(\mu \mathrm{M})\end{array}$} & \multirow{2}{*}{$\begin{array}{c}\mathrm{Sr} \\
(\mu \mathrm{M})\end{array}$} & \multirow{2}{*}{$\begin{array}{c}\mathrm{Ba} \\
(\mathrm{nM})\end{array}$} & \multirow{2}{*}{$\begin{array}{c}\mathrm{H}_{4} \mathrm{SiO}_{4} \\
(\mu \mathrm{M})\end{array}$} \\
\hline & Top & Bottom & & & & & & \\
\hline $47 X-2,95-130$ & 379.4 & 379.7 & 22.7 & 224 & 2.23 & 29.8 & 4515 & 429 \\
\hline $48 X-1,96-122$ & 382.9 & 383.1 & 22.4 & 233 & 2.06 & 28.7 & 4070 & 351 \\
\hline $49 X-3,106-138$ & 394.7 & 395.0 & 26.5 & 191 & 2.05 & 22.2 & 2834 & 215 \\
\hline $50 X-2,97-129$ & 402.3 & 402.6 & 25.0 & 193 & 1.90 & 21.3 & 2588 & 262 \\
\hline $51 X-5,85-117$ & 416.0 & 416.3 & 25.5 & 239 & 2.38 & 22.5 & 2352 & 301 \\
\hline $52 X-5,70-102$ & 425.0 & 425.3 & 25.0 & 192 & 1.64 & 27.3 & 2570 & 264 \\
\hline $53 X-3,53-85$ & 430.7 & 431.0 & 24.7 & 217 & 2.63 & 28.1 & 2959 & 285 \\
\hline $54 X-5,104-140$ & 444.2 & 444.6 & & & & & & 212 \\
\hline $55 X-2,81-117$ & 448.8 & 449.2 & 22.5 & 210 & 1.42 & 33.9 & 2797 & \\
\hline $56 \mathrm{X}-2,64-76$ & 458.2 & 458.4 & 27.0 & 228 & 1.03 & 36.5 & 2197 & 184 \\
\hline $57 X-3,63-99$ & 469.3 & 469.7 & 34.3 & 214 & 0.49 & 39.1 & 1670 & 148 \\
\hline $58 X-2,90-126$ & 478.3 & 478.6 & & & & & & \\
\hline $59 X-4,93-125$ & 489.7 & 490.0 & 59.1 & 250 & 0.55 & 45.3 & 1909 & 196 \\
\hline $60 X-4,60-92$ & 499.7 & 500.0 & 55.3 & 181 & 0.52 & 36.4 & 2247 & 219 \\
\hline $61 X-4,102-138$ & 510.1 & 510.5 & 56.6 & 192 & 0.69 & 33.8 & 2561 & 194 \\
\hline $62 X-1,54-81$ & 510.2 & 510.5 & 55.5 & 233 & 1.08 & 37.7 & 2979 & \\
\hline \multirow[t]{2}{*}{$63 X-4,84-122$} & 518.7 & 519.1 & 50.3 & 181 & 0.79 & 33.0 & 2622 & 169 \\
\hline & \multicolumn{2}{|c|}{ Limit of detection: } & 0.82 & 4.3 & 0.19 & 0.67 & 84 & \\
\hline
\end{tabular}

Table T2. Minor element concentrations in pore fluids, Site U1379. (Continued on next two pages.)

\begin{tabular}{|c|c|c|c|c|c|c|c|c|}
\hline \multirow{2}{*}{$\begin{array}{l}\text { Core, section, } \\
\text { interval }(\mathrm{cm})\end{array}$} & \multicolumn{2}{|c|}{ Depth (mbsf) } & \multirow{2}{*}{$\begin{array}{c}\mathrm{Li} \\
(\mu \mathrm{M})\end{array}$} & \multirow{2}{*}{$\begin{array}{c}\mathrm{B} \\
(\mu \mathrm{M})\end{array}$} & \multirow{2}{*}{$\begin{array}{c}\mathrm{Mn} \\
(\mu \mathrm{M})\end{array}$} & \multirow{2}{*}{$\begin{array}{c}\mathrm{Sr} \\
(\mu \mathrm{M})\end{array}$} & \multirow{2}{*}{$\begin{array}{c}\mathrm{Ba} \\
(\mathrm{nM})\end{array}$} & \multirow{2}{*}{$\begin{array}{r}\mathrm{H}_{4} \mathrm{SiO}_{4} \\
(\mu \mathrm{M})\end{array}$} \\
\hline & Top & Bottom & & & & & & \\
\hline \multicolumn{9}{|l|}{ 334-U1379B- } \\
\hline $1 \mathrm{H}-1,70-80$ & 0.7 & 0.8 & 27.0 & 444 & 1.59 & 91.1 & 157 & 95 \\
\hline $2 \mathrm{H}-1,110-120$ & 2.1 & 2.2 & 24.7 & 472 & 7.13 & 81.0 & 369 & 433 \\
\hline $2 \mathrm{H}-2,35-45$ & 2.9 & 3.0 & 23.4 & 458 & 6.18 & 78.5 & 342 & 470 \\
\hline $2 \mathrm{H}-2,110-120$ & 3.6 & 3.7 & 24.6 & 476 & 6.21 & 80.1 & 408 & 422 \\
\hline $2 \mathrm{H}-3,35-45$ & 4.4 & 4.5 & 22.6 & 444 & 5.49 & 73.0 & 361 & 458 \\
\hline $2 \mathrm{H}-3,110-120$ & 5.1 & 5.2 & 22.2 & 409 & 4.60 & 73.8 & 383 & 395 \\
\hline $2 \mathrm{H}-4,35-35$ & 5.9 & 6.0 & & & & & & 509 \\
\hline $2 \mathrm{H}-4,110-120$ & 6.6 & 6.7 & 21.6 & 433 & 4.24 & 64.8 & 391 & 466 \\
\hline $2 \mathrm{H}-5,88-98$ & 7.9 & 8.0 & 24.0 & 404 & 3.14 & 56.6 & 268 & 458 \\
\hline \multicolumn{9}{|l|}{ 334-U1379C- } \\
\hline $1 \mathrm{H}-1,140-150$ & 1.4 & 1.5 & 25.5 & 454 & & 83.6 & 334 & 290 \\
\hline $1 \mathrm{H}-2,140-150$ & 2.9 & 3.0 & 23.5 & 428 & & 81.7 & 418 & 378 \\
\hline $1 \mathrm{H}-3,140-150$ & 4.4 & 4.5 & 22.8 & 435 & & 77.7 & 457 & 427 \\
\hline $1 \mathrm{H}-4,140-150$ & 5.9 & 6.0 & 21.3 & 425 & & 70.4 & 534 & 431 \\
\hline $1 \mathrm{H}-5,50-60$ & 6.5 & 6.6 & 21.3 & 417 & & 66.8 & 553 & 468 \\
\hline $2 \mathrm{H}-1,140-150$ & 8.1 & 8.2 & 21.7 & 427 & & 62.4 & 549 & 515 \\
\hline $2 \mathrm{H}-2,140-150$ & 9.6 & 9.7 & 22.9 & 423 & & 56.8 & 430 & 504 \\
\hline $2 \mathrm{H}-3,140-150$ & 11.1 & 11.2 & 23.6 & 438 & & 53.9 & 349 & 508 \\
\hline $2 \mathrm{H}-4,140-150$ & 12.6 & 12.7 & 24.2 & 468 & & 54.3 & 430 & 530 \\
\hline $2 \mathrm{H}-5,140-150$ & 14.1 & 14.2 & 21.9 & 446 & & 47.5 & 382 & 518 \\
\hline $2 \mathrm{H}-6,36-46$ & 14.6 & 14.7 & 22.4 & 453 & & 45.8 & 373 & 436 \\
\hline $3 \mathrm{H}-1,138-148$ & 17.6 & 17.7 & 23.0 & 429 & & 46.6 & 307 & 433 \\
\hline $3 \mathrm{H}-2,138-148$ & 19.1 & 19.2 & 23.4 & 432 & & 46.6 & 287 & 447 \\
\hline $3 \mathrm{H}-3,138-148$ & 20.6 & 20.7 & 23.8 & 419 & & 45.6 & 229 & 396 \\
\hline $3 \mathrm{H}-4,138-148$ & 22.1 & 22.2 & 24.6 & 448 & & 46.2 & 240 & 404 \\
\hline $3 \mathrm{H}-5,138-148$ & 23.6 & 23.7 & 24.6 & 428 & & 46.7 & 268 & 354 \\
\hline $3 \mathrm{H}-6,39-39$ & 24.1 & 24.2 & 25.2 & 444 & 1.72 & 47.2 & 133 & 352 \\
\hline $4 \mathrm{H}-2,138-148$ & 27.1 & 27.2 & 25.9 & 431 & & 50.0 & 256 & 307 \\
\hline $4 \mathrm{H}-4,92-102$ & 29.6 & 29.7 & 26.7 & 448 & & 54.9 & 220 & 289 \\
\hline $5 \mathrm{H}-2,138-148$ & 33.1 & 33.2 & 24.1 & 431 & & 51.7 & 231 & 251 \\
\hline $5 \mathrm{H}-4,149-159$ & 36.2 & 36.3 & 21.1 & 414 & & 53.6 & 327 & 309 \\
\hline $6 \mathrm{H}-2,138-148$ & 39.4 & 39.5 & 20.1 & 433 & & 55.5 & 392 & 332 \\
\hline $6 \mathrm{H}-4,138-148$ & 42.4 & 42.5 & 17.1 & 419 & & 55.9 & 551 & 396 \\
\hline 7H-2, 138-148 & 45.4 & 45.5 & 16.6 & 436 & & 55.3 & 852 & 435 \\
\hline 7H-4, 136-146 & 48.4 & 48.5 & 17.2 & 427 & & 56.8 & 569 & 383 \\
\hline $8 \mathrm{H}-2,138-148$ & 52.0 & 52.1 & 17.8 & 424 & & 58.9 & 504 & 360 \\
\hline $8 \mathrm{H}-4,130-140$ & 54.9 & 55.0 & 18.3 & 440 & & 61.8 & 393 & 391 \\
\hline $9 \mathrm{H}-2,138-148$ & 58.4 & 58.5 & 20.0 & 420 & & 67.5 & 360 & 358 \\
\hline $9 \mathrm{H}-4,128-138$ & 61.3 & 61.4 & 22.5 & 365 & & 72.5 & 304 & 267 \\
\hline $10 \mathrm{H}-1,88-98$ & 62.4 & 62.5 & 21.6 & 380 & & 79.8 & 298 & \\
\hline $11 \mathrm{H}-1,138-148$ & 64.9 & 65.0 & 19.3 & 408 & & 81.2 & 608 & 278 \\
\hline $11 \mathrm{H}-3,78-88$ & 67.3 & 67.4 & 16.5 & 288 & & 71.7 & 712 & 171 \\
\hline
\end{tabular}


Table T2 (continued). (Continued on next page.)

\begin{tabular}{|c|c|c|c|c|c|c|c|c|}
\hline \multirow{2}{*}{$\begin{array}{l}\text { Core, section, } \\
\text { interval }(\mathrm{cm})\end{array}$} & \multicolumn{2}{|c|}{ Depth (mbsf) } & \multirow{2}{*}{$\begin{array}{c}\mathrm{Li} \\
(\mu \mathrm{M})\end{array}$} & \multirow{2}{*}{$\begin{array}{c}\text { B } \\
(\mu \mathrm{M})\end{array}$} & \multirow{2}{*}{$\begin{array}{r}\mathrm{Mn} \\
(\mu \mathrm{M})\end{array}$} & \multirow{2}{*}{$\begin{array}{c}\mathrm{Sr} \\
(\mu \mathrm{M})\end{array}$} & \multirow{2}{*}{$\begin{array}{c}\mathrm{Ba} \\
(\mathrm{nM})\end{array}$} & \multirow{2}{*}{$\begin{array}{c}\mathrm{H}_{4} \mathrm{SiO}_{4} \\
(\mu \mathrm{M})\end{array}$} \\
\hline & Top & Bottom & & & & & & \\
\hline $12 \mathrm{H}-2,138-148$ & 70.6 & 70.7 & 17.6 & 358 & & 75.6 & 698 & 258 \\
\hline $12 \mathrm{H}-4,103-103$ & 73.2 & 73.3 & 15.6 & 311 & 0.94 & 65.5 & 433 & 239 \\
\hline $13 \mathrm{H}-2,138-148$ & 76.6 & 76.7 & 14.4 & 311 & & 61.5 & 478 & 202 \\
\hline $14 \mathrm{H}-2,138-138$ & 81.6 & 81.7 & 12.3 & 232 & 1.22 & 56.2 & 239 & 127 \\
\hline $15 \mathrm{H}-3,100-110$ & 86.2 & 86.3 & 14.1 & 278 & & 59.9 & 433 & 216 \\
\hline $16 \mathrm{H}-2,138-138$ & 89.4 & 89.5 & 13.5 & 222 & 1.86 & 58.8 & 340 & 95 \\
\hline $17 \mathrm{H}-1,76-76$ & 91.0 & 91.1 & 14.4 & 263 & 2.80 & 61.8 & 395 & 118 \\
\hline $20 X-1,137-137$ & 112.1 & 112.2 & 14.8 & 273 & 2.99 & 66.8 & 790 & 193 \\
\hline $20 X-3,137-147$ & 115.1 & 115.2 & 14.9 & 262 & & 67.9 & 1051 & 206 \\
\hline $21 X-3,133-133$ & 124.8 & 124.9 & 13.9 & 268 & 1.87 & 68.6 & 670 & 171 \\
\hline $22 X-3,137-137$ & 133.5 & 133.6 & 13.3 & 244 & & 69.8 & 908 & 134 \\
\hline $22 X-6,138-138$ & 138.0 & 138.1 & 11.6 & 205 & 0.87 & 66.4 & 847 & 102 \\
\hline $23 X-1,138-148$ & & & 14.4 & 253 & & 68.7 & 944 & 176 \\
\hline $23 X-6,113-123$ & & & 13.8 & 197 & & 68.5 & 1136 & \\
\hline $24 X-3,133-148$ & 154.2 & 154.4 & 13.3 & 254 & & 68.2 & 1329 & 233 \\
\hline $24 \mathrm{X}-6,124-139$ & 158.6 & 158.8 & 9.7 & 176 & & 61.8 & 1461 & 110 \\
\hline $25 X-3,133-148$ & 164.0 & 164.2 & 15.1 & 212 & & 64.7 & 1445 & 255 \\
\hline $25 X-5,128-143$ & 167.0 & 167.2 & 17.3 & 265 & & 61.2 & 1388 & 256 \\
\hline $26 \mathrm{X}-3,133-148$ & 178.1 & 178.3 & 20.7 & 206 & & 54.7 & 1554 & 178 \\
\hline $26 \mathrm{X}-6,113-130$ & 178.1 & 178.3 & 22.0 & 216 & 1.47 & 52.8 & 1360 & 204 \\
\hline $27 X-3,133-150$ & 183.6 & 183.8 & 21.3 & 239 & 1.51 & 49.0 & 852 & 165 \\
\hline $27 X-6,113-130$ & 187.9 & 188.1 & 20.1 & 209 & & 47.3 & 751 & 166 \\
\hline $28 X-3,133-133$ & 192.3 & 192.4 & 22.2 & 265 & 1.71 & 47.6 & 595 & \\
\hline $28 X-6,133-143$ & 196.7 & 196.8 & 22.4 & 254 & & 47.0 & 696 & 202 \\
\hline $29 X-1,133-150$ & 200.2 & 200.4 & & & & & & \\
\hline $29 X-4,120-137$ & 204.5 & 204.7 & 22.5 & 220 & 2.32 & 45.4 & 737 & 183 \\
\hline $30 X-2,133-143$ & 211.5 & 211.6 & 23.2 & 277 & & 46.7 & 892 & 215 \\
\hline $30 X-5,123-133$ & 215.4 & 215.5 & 22.6 & 264 & & 45.7 & 965 & 128 \\
\hline $31 X-2,133-148$ & 219.3 & 219.5 & 22.2 & 234 & & 50.6 & 1213 & 133 \\
\hline $31 X-5,133-148$ & 223.8 & 224.0 & 18.5 & 182 & & 47.1 & 1125 & 224 \\
\hline $32 X-2,133-148$ & 229.1 & 229.3 & 21.4 & 206 & & 51.5 & 1178 & \\
\hline $32 X-6,133-133$ & 235.1 & 235.3 & 18.6 & 172 & 2.31 & 52.3 & 707 & 108 \\
\hline $33 X-5,78-100$ & 262.5 & 262.7 & 29.9 & 229 & 2.89 & 62.4 & 737 & \\
\hline $34 X-3,128-148$ & 250.2 & 250.4 & 36.5 & 209 & & 65.1 & 894 & 222 \\
\hline $35 X-5,78-100$ & 262.5 & 262.7 & 31.8 & 189 & 1.98 & 61.4 & 615 & 182 \\
\hline $36 X-5,128-128$ & 271.7 & 271.9 & 28.4 & 218 & & 58.6 & 725 & 185 \\
\hline $37 X-5,128-128$ & 282.6 & 282.8 & 32.2 & 243 & 1.93 & 53.0 & 608 & 204 \\
\hline $38 X-5,128-128$ & 292.4 & 292.6 & 29.4 & 170 & & 47.0 & 1158 & 129 \\
\hline $39 X-3,129-129$ & 299.2 & 299.4 & 31.0 & 199 & 1.87 & 47.0 & 1100 & 404 \\
\hline $40 X-4,100-122$ & 310.2 & 310.4 & 32.7 & 165 & 2.15 & 48.1 & 1566 & 249 \\
\hline $41 X-4,128-128$ & 320.3 & 320.5 & 34.0 & 167 & 1.79 & 51.4 & 1993 & 435 \\
\hline $42 X-3,123-145$ & 328.4 & 328.7 & 37.2 & 276 & & 68.6 & 5226 & 416 \\
\hline $43 X-6,81-107$ & 341.4 & 341.7 & 29.4 & 144 & $<\mathrm{dl}$ & 72.6 & 2332 & 141 \\
\hline $44 X-6,78-107$ & 350.9 & 351.2 & 31.6 & 148 & & 87.7 & 4203 & 246 \\
\hline $45 X-4,118-140$ & 358.4 & 358.6 & 34.7 & 146 & & 102.8 & 7210 & \\
\hline $46 X-5,75-100$ & 368.5 & 368.7 & 30.8 & 125 & 1.87 & 91.5 & 7422 & 275 \\
\hline $47 X-5,133-156$ & 378.0 & 378.3 & & & & & & 370 \\
\hline $48 X-6,63-63$ & 386.4 & 386.5 & 26.6 & 134 & 1.35 & 95.0 & 5701 & 137 \\
\hline $49 X-6,75-100$ & 395.9 & 396.1 & 21.7 & 152 & & 90.9 & 5555 & 299 \\
\hline $50 X-5,104-132$ & 405.1 & 405.4 & 21.7 & 117 & 0.69 & 79.2 & 2816 & 110 \\
\hline $51 X-4,104-129$ & 412.5 & 412.8 & 27.3 & 163 & & 80.1 & 2308 & 194 \\
\hline $52 X-2,118-118$ & 420.1 & 420.3 & 31.5 & 149 & 1.77 & 72.5 & 1676 & 171 \\
\hline $53 X-3,118-118$ & 430.4 & 430.6 & 33.9 & 143 & & 69.7 & 1479 & 158 \\
\hline $54 X-4,75-75$ & 439.6 & 439.8 & 41.2 & 158 & 2.96 & 72.5 & 3201 & 138 \\
\hline $55 X-3,87-87$ & 448.1 & 448.3 & 37.2 & 130 & & 65.6 & 2981 & \\
\hline $56 X-4,100-100$ & 458.7 & 458.9 & 41.3 & 115 & 2.47 & 62.4 & 2856 & 127 \\
\hline $57 X-3,118-150$ & 467.6 & 467.9 & 40.4 & 119 & & 62.6 & 4109 & 166 \\
\hline $58 X-4,90-90$ & 477.5 & 477.8 & 36.3 & 82 & 4.52 & 56.5 & 4780 & 220 \\
\hline $59 X-4,106-138$ & 486.7 & 487.0 & 29.8 & 109 & & 55.5 & 4947 & 186 \\
\hline $60 X-4,118-150$ & 496.4 & 496.7 & 29.8 & 99 & 6.46 & 52.0 & 4422 & 138 \\
\hline $61 X-5,118-118$ & 507.6 & 507.8 & 30.6 & 175 & & 55.8 & 2154 & 134 \\
\hline $62 X-4,68-100$ & 514.5 & 514.8 & 32.0 & 164 & 3.90 & 57.1 & 1691 & 144 \\
\hline $63 X-5,118-118$ & 524.9 & 525.1 & 36.7 & 158 & & 57.5 & 1686 & \\
\hline $64 X-5,125-150$ & 534.4 & 534.6 & 40.2 & 164 & 1.97 & 53.2 & 1320 & 123 \\
\hline $65 X-6,78-114$ & 545.1 & 545.4 & 35.0 & 152 & 2.16 & 45.0 & 1070 & 132 \\
\hline $66 \mathrm{X}-6,66-100$ & 554.2 & 554.5 & & & & & & \\
\hline $67 X-6,70-70$ & 563.8 & 564.1 & 37.1 & 132 & 1.83 & 39.0 & 1763 & 127 \\
\hline $68 X-4,88-120$ & 570.4 & 570.7 & 38.1 & 179 & 3.02 & 40.6 & 1775 & \\
\hline $69 \times-3,93-93$ & 578.3 & 578.6 & 34.9 & 174 & & 45.9 & 2549 & 137 \\
\hline $70 X-4,92-92$ & 589.7 & 590.0 & 39.3 & 164 & 9.28 & 54.1 & 4622 & 129 \\
\hline
\end{tabular}


Table T2 (continued).

\begin{tabular}{|c|c|c|c|c|c|c|c|c|}
\hline \multirow{2}{*}{$\begin{array}{l}\text { Core, section, } \\
\text { interval }(\mathrm{cm})\end{array}$} & \multicolumn{2}{|c|}{ Depth (mbsf) } & \multirow{2}{*}{$\begin{array}{c}\mathrm{Li} \\
(\mu \mathrm{M})\end{array}$} & \multirow{2}{*}{$\begin{array}{c}\text { B } \\
(\mu \mathrm{M})\end{array}$} & \multirow{2}{*}{$\begin{array}{c}\mathrm{Mn} \\
(\mu \mathrm{M})\end{array}$} & \multirow{2}{*}{$\begin{array}{c}\mathrm{Sr} \\
(\mu \mathrm{M})\end{array}$} & \multirow{2}{*}{$\begin{array}{c}\mathrm{Ba} \\
(\mathrm{nM})\end{array}$} & \multirow{2}{*}{$\begin{array}{c}\mathrm{H}_{4} \mathrm{SiO}_{4} \\
(\mu \mathrm{M})\end{array}$} \\
\hline & Top & Bottom & & & & & & \\
\hline $71 X-4,64-64$ & 598.5 & 598.8 & 43.1 & 157 & & 64.0 & 3799 & 145 \\
\hline $72 X-2,88-120$ & 605.3 & 605.6 & 55.5 & 175 & 1.99 & 66.5 & 2521 & 208 \\
\hline $73 X-5,116-150$ & 619.6 & 619.9 & 60.6 & 141 & 1.36 & 65.7 & 2366 & 136 \\
\hline $74 X-4,74-107$ & 626.3 & 626.7 & 65.6 & 172 & 1.38 & 71.9 & 2943 & 138 \\
\hline $75 X-4,86-120$ & 636.4 & 636.7 & 65.0 & 159 & 1.20 & 66.9 & 2964 & 171 \\
\hline $76 X-3,118-150$ & 645.2 & 645.5 & 64.6 & 157 & 1.28 & 66.4 & 2462 & 113 \\
\hline $77 X-2,118-150$ & 648.5 & 648.8 & 59.8 & 138 & 1.16 & 64.0 & 2288 & \\
\hline $78 X-4,110-150$ & 656.6 & 657.0 & 63.6 & 143 & 1.18 & 64.8 & 2932 & 104 \\
\hline 79X-4, 70-100 & 665.0 & 665.3 & 61.6 & 117 & 1.00 & 62.3 & 3186 & 119 \\
\hline $80 X-4,93-125$ & 674.7 & 675.1 & 63.4 & 141 & 1.62 & 58.6 & 3438 & \\
\hline $81 X-2,100-132$ & 682.0 & 682.3 & 67.4 & 155 & 1.53 & 61.4 & 3619 & 214 \\
\hline $82 X-3,70-102$ & 692.6 & 692.9 & 65.6 & 152 & 1.64 & 62.6 & 2511 & \\
\hline $83 X-1,60-92$ & 699.8 & 700.1 & 64.8 & 173 & 1.72 & 65.7 & 2012 & 131 \\
\hline $84 X-3,56-88$ & 712.4 & 712.7 & 53.0 & 167 & 1.65 & 67.0 & 1194 & 135 \\
\hline $85 X-1,77-112$ & 717.2 & 717.5 & 50.0 & 126 & 1.00 & 73.4 & 1396 & 116 \\
\hline $86 \mathrm{X}-2,87-119$ & 728.5 & 728.8 & & & & & & \\
\hline $88 X-1,118-150$ & 746.6 & 746.9 & & & & & & \\
\hline $89 \mathrm{X}-2,0-40$ & 751.6 & 752.0 & 48.8 & 103 & 1.14 & 66.1 & 1289 & 110 \\
\hline $91 X-4,50-85$ & 770.3 & 770.7 & 50.1 & 99 & 1.24 & 56.3 & 1161 & \\
\hline $92 X-3,94-131$ & 778.9 & 779.3 & 60.4 & 153 & 1.47 & 53.0 & 1034 & 125 \\
\hline $93 X-1,22-50$ & 785.2 & 785.5 & & & & & & \\
\hline $94 X-1,56-91$ & 795.1 & 795.4 & & & & & & \\
\hline $95 X-3,118-150$ & 807.5 & 807.8 & 54.1 & 135 & 2.15 & 39.4 & 840 & 86 \\
\hline $97 X-2,68-100$ & 824.8 & 825.1 & & & & & & \\
\hline $98 X-4,79-115$ & 837.3 & 837.6 & 76.5 & 318 & 4.33 & 36.5 & 934 & 176 \\
\hline $99 X-2,118-150$ & 844.2 & 844.5 & 70.5 & 119 & 2.80 & 46.4 & 1641 & \\
\hline $100 X-2,56-88$ & 852.7 & 853.0 & & & & & & \\
\hline $101 X-4,58-90$ & 865.3 & 865.6 & & & & & & \\
\hline $102 X-5,110-140$ & 877.4 & 877.7 & & & & & & \\
\hline \multirow[t]{2}{*}{$103 X-2,34-60$} & 881.2 & 881.5 & & & & & & 66 \\
\hline & \multicolumn{2}{|c|}{ Limit of detection: } & 2.4 & 6.4 & 0.28 & 1.1 & 70 & \\
\hline
\end{tabular}

$\mathrm{dl}=$ detection limit.

Table T3. Minor element concentration in pore fluids, Site U1381.

\begin{tabular}{|c|c|c|c|c|c|c|c|c|}
\hline \multirow{2}{*}{$\begin{array}{l}\text { Core, section, } \\
\text { interval }(\mathrm{cm})\end{array}$} & \multicolumn{2}{|c|}{ Depth (mbsf) } & \multirow{2}{*}{$\begin{array}{c}\mathrm{Li} \\
(\mu \mathrm{M})\end{array}$} & \multirow{2}{*}{$\begin{array}{c}\text { B } \\
(\mu \mathrm{M})\end{array}$} & \multirow{2}{*}{$\begin{array}{c}\mathrm{Mn} \\
(\mu \mathrm{M})\end{array}$} & \multirow{2}{*}{$\begin{array}{c}\mathrm{Sr} \\
(\mu \mathrm{M})\end{array}$} & \multirow{2}{*}{$\begin{array}{c}\mathrm{Ba} \\
(\mathrm{nM})\end{array}$} & \multirow{2}{*}{$\begin{array}{c}\mathrm{H}_{4} \mathrm{SiO}_{4} \\
(\mu \mathrm{M})\end{array}$} \\
\hline & Top & Bottom & & & & & & \\
\hline \multicolumn{9}{|l|}{ 334-U1381A- } \\
\hline $3 R-1,61-71$ & 13.0 & 13.1 & 20.4 & 554 & 3.05 & 80.2 & 362 & 644 \\
\hline $4 R-1,46-56$ & 22.8 & 22.9 & 22.5 & 517 & 3.12 & 81.7 & 554 & 656 \\
\hline $5 \mathrm{R}-2,135-150$ & 34.8 & 34.9 & 24.2 & 508 & 3.78 & 83.2 & 497 & 719 \\
\hline $6 \mathrm{R}-3,135-150$ & 45.9 & 46.0 & 27.9 & 502 & 3.22 & 86.8 & 479 & 726 \\
\hline 7R-2, 60-75 & 52.9 & 53.0 & 30.9 & 489 & 4.00 & 92.3 & 378 & 951 \\
\hline $8 R-2,135-150$ & 63.6 & 63.7 & 33.0 & 495 & 5.25 & 97.4 & 367 & 860 \\
\hline $8 R-4,135-150$ & 66.6 & 66.7 & 33.2 & 490 & 4.95 & 97.9 & 385 & 980 \\
\hline $9 \mathrm{R}-1,135-150$ & 71.7 & 71.8 & 34.1 & 493 & 4.89 & 102.8 & 427 & 925 \\
\hline $9 R-3,135-150$ & 74.7 & 74.8 & 35.0 & 497 & 4.80 & 104.0 & 335 & 984 \\
\hline 10R-1, 145-158 & 81.4 & 81.5 & 34.2 & 470 & 5.17 & 103.1 & 384 & 826 \\
\hline $11 \mathrm{R}-1,135-150$ & 90.9 & 91.0 & 34.7 & 480 & 6.95 & 103.0 & 381 & 959 \\
\hline $11 \mathrm{R}-3,120-135$ & 93.7 & 93.9 & 34.1 & 451 & 6.85 & 99.2 & 730 & 1077 \\
\hline \multicolumn{9}{|l|}{ 334-U1381B- } \\
\hline 1R-1, 100-115 & 1.0 & 1.2 & 23.8 & 539 & 14.00 & 84.1 & 333 & 538 \\
\hline 1R-2, 100-115 & 2.2 & 2.3 & 22.0 & 557 & 8.86 & 83.6 & 293 & 560 \\
\hline 1R-3, 150-165 & 3.8 & 4.0 & 19.9 & 541 & 5.53 & 80.4 & 256 & 599 \\
\hline $2 \mathrm{R}-2,130-150$ & 12.2 & 12.4 & 20.2 & 549 & 4.91 & 81.0 & 293 & 586 \\
\hline \multirow[t]{2}{*}{$3 R-4,100-120$} & 24.5 & 24.7 & 22.5 & 543 & 2.64 & 81.7 & 523 & 637 \\
\hline & \multicolumn{2}{|c|}{ Limit of detection: } & 2.4 & 6.4 & 0.28 & 1.1 & 70 & \\
\hline
\end{tabular}

